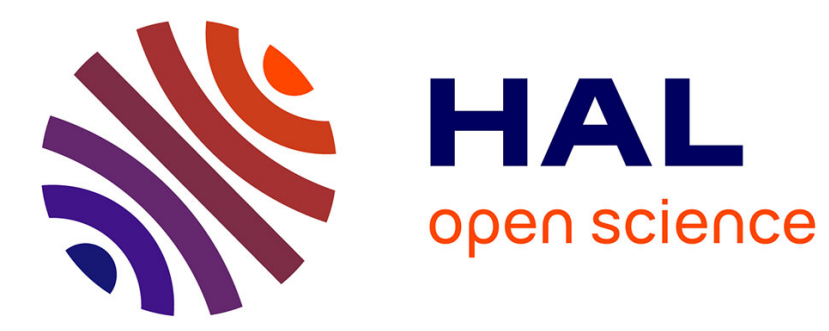

\title{
CSR and Market Valuation: International Evidence
}

Sylvain Marsat, Benjamin Williams

\section{To cite this version:}

Sylvain Marsat, Benjamin Williams. CSR and Market Valuation: International Evidence. Bankers Markets \& Investors : an academic \& professional review, 2013, 123, pp.29 - 42. 10.2139/ssrn.1833581 . hal-02156596

\section{HAL Id: hal-02156596 https://hal.science/hal-02156596}

Submitted on 14 Jun 2019

HAL is a multi-disciplinary open access archive for the deposit and dissemination of scientific research documents, whether they are published or not. The documents may come from teaching and research institutions in France or abroad, or from public or private research centers.
L'archive ouverte pluridisciplinaire HAL, est destinée au dépôt et à la diffusion de documents scientifiques de niveau recherche, publiés ou non, émanant des établissements d'enseignement et de recherche français ou étrangers, des laboratoires publics ou privés. 


\title{
CSR and Market Valuation: International Evidence
}

\author{
Sylvain MARSAT \\ Clermont Université \\ Université d'Auvergne, EA 3849 CRCGM \\ Faculty of Economics and Management \\ IAE Clermont-Fd \\ 41, Bd F.-Mitterrand BP 54 \\ F-63002 Clermont-Fd Cedex - France \\ Tel: +3347317 7588 \\ E-Mail: sylvain.marsat@u-clermont1.fr
}

\author{
Benjamin WILLIAMS \\ Clermont Université \\ Université d'Auvergne, EA 3849 CRCGM \\ Faculty of Economics and Management \\ IAE Clermont-Fd \\ 41, Bd F.-Mitterrand BP 54 \\ F-63002 Clermont-Fd Cedex - France \\ Tel: +3347317 7587 \\ E-Mail: benjamin.williams@u-clermont1.fr
}

Version accepted for publication in:

Marsat, S., Williams, B., 2013. CSR and Market Valuation: International Evidence. Bankers, Markets \& Investors 123, 29-42

\begin{abstract}
Do socially responsible firms benefit from ethical goodwill? On the one hand, taking externalities into account can be a competitive disadvantage. On the other hand, financial benefits may result from ethical behavior. Thanks to a worldwide dataset of ESG ratings (MSCI ESG ratings), we examine the relationship between a firm's CSR rating and its shareholder value. After controlling for industry, region, year and R\&D, we observe, contrary to mainstream empirical studies, strong evidence of a negative impact of responsible behavior on corporate market value. More precisely, environmental performance was penalized by investors over the 2005-2009 period, whereas involvement in human capital seems to have been valued by the market.
\end{abstract}

Keywords: Corporate Social Responsibility, ESG Rating, Firm valuation, Tobin's $q$

JEL classification: $\mathrm{G} 11, \mathrm{G} 12$ 
After decades of initial insights on social responsibility, including Bowen's (1953) seminal book, consciousness of extra-financial bottom lines, like social and environmental issues, really emerged at an international scale after the UNO-Brundtland Report of 1987. According to this report, it is important not to handicap future generations and the economy should balance profitability with its consequences for people and the planet. Taking externalities into account is the only way to achieve global and long-term equilibrium.

At a governmental level, measures like the New Economic Regulations in France oblige companies to disclose social and environmental issues. Some pension plans, for instance in the UK since the 1995 Pension act, have to disclose their environmental and ethics policies. Furthermore, since environmental scandals like the Exxon Valdes, some investors feel more concerned by the extra-financial implications of a firm's business, such as its image among consumers concerned by fair trade. Companies are therefore encouraged to promote their corporate social responsibility.

In the mainstream theory of finance, however, the only goal of the firm is to maximize shareholder wealth (Friedman, 1962). The purpose of a firm is not to act in the moral sphere or in the place of the government, but merely to do business (Levitt, 1958). From a neoclassical point of view, the firm should therefore not take externalities into account since the money spent on "moral" stakes is lost for shareholders. This makes the firm less efficient, with higher costs stemming from this additional constraint. In the long term, the company will not be able to compete with its less scrupulous competitors. Doing 'good' is therefore considered counterproductive from a purely financial standpoint (Shleifer, 2004).

On the other hand, proponents of the stakeholder theory (Freeman, 1984; Donaldson and Preston, 1995) believe that ethical behavior and profit are not mutually exclusive. While money spent on ethical issues is not paid to shareholders over the short term, it might enable the firm to be more profitable in the future. For instance, ethical behavior can lead to reputational advantages, such as attraction of sensitive consumers (Guenster et al., 2010), and help avoid social problems as well as environmental disasters. Investing in the moral area can be seen as an opportunity to protect the firm against future risks (Godfrey et al., 2009).

From an empirical point of view, results concerning the link between profitability and ethical behavior are mixed. Whether it is rewarding to behave ethically ("doing well while doing good", Hamilton et al., 1993) or there is "a price of ethics" (Renneboog et al., 2007, Dupré et al., 2006) both for investors and firms, is still a crucial debate. On the environmental side, Horváthová (2010) reports a majority of positive relationships between environmental performance and economic performance. However, there is no clear consensus and the results depend on the econometrics used, the type of legal system (common or civil law), the data timeframe and the kind of environmental variable. Whereas Margolis and Walsh (2001) question the evidence of the studies on the corporate social - financial link, Orlitzky et al. (2003) suggest in their meta-analysis that social responsibility pays off.

Only a few studies, however, really analyze the precise relationship between Corporate Social Responsibility (henceforth CSR) practices and shareholder value. Theoretically, if investors consider CSR as value sharing with employees, for instance, or an environmental commitment at the expense of shareholders, they might penalize it from a valuation standpoint. On the other hand, shareholders may also view social responsibility as an opportunity for value creation, avoiding lawsuits, increasing the firm's reputation and consumer attractiveness, which all lead to interesting future benefits. Tobin's $q$ is often seen as a proxy of financial performance, but not as an assessment of firm valuation. We assume in this paper that market valuation is not a performance indicator of the same nature as Return 
on Assets and Return on Equity on the company side or stock returns on the investor's side. Rather, market valuation is the perception of shareholder value by investors at a specific date. On efficient markets, valuation indicators like Tobin's $q$ also include the measure of intangible assets by investors (Villalonga, 2004) that are incorporated into prices. Therefore, market valuation seems to be a particularly interesting proxy to measure investors' expectations on the worthiness of the stock, i.e. the price, relative to book value, at which agents agree to exchange their shares on the market. Specifically, we wonder if CSR practices lead to an ethical goodwill by studying the impact of CSR behavior on stock valuation.

Our contribution to the existing literature on the link between CSR and market value is fourfold. First, we measure CSR practices through a rarely used but reliable, complete and worldwide database, MSCI ESG ratings (formerly Innovest and RiskMetrics). This dataset enables us to capture the entire CSR rating (IVA rating) and its subsets (Environmental, Social, Stakeholders and Corporate governance) on a wide sample of almost 9,000 observations. More specifically, our sample is composed of 2,838 firms from 50 countries over the 2005-2009 period. Second, as methodology is often called into question (Byrd et al., 2007), we follow rigorous checks of robustness by using different proxies for firm valuation and introducing numerous control variables such as R\&D, industry and region. Third, the results are stimulating since they clearly indicate an undervaluation of firms that have high CSR ratings. This calls into question prior evidence (e.g. Galema, 2008; Guenster et al., 2010). Fourth, we find different levels of sensitivity among investors to different CSR dimensions. While the negative link between the firm's value and CSR is driven by the environmental score, investors seem, on the other hand, to positively value involvement in human capital.

The remaining part of this paper is organized as follows. The first section deals with the prior literature on CSR and stock valuation. The second section focuses on methodology and data. The third section provides a discussion of the results.

\section{CSR AND VALUE: RELATED LITERATURE}

Corporate Social Responsibility is a widely employed notion. According to Dahlsrud (2008), the most common definition is given by the European Commission, as "a concept whereby companies integrate social and environmental concerns in their business operations and in their interaction with their stakeholders on a voluntary basis" (Commission of the European Communities, 2001). We investigate the way investors actually value corporate social responsibility and therefore price it on the market. Prior theoretical and empirical research that discusses this issue is reviewed.

\section{I.1. THEORETICAL BACKGROUND OF CSR VALUATION}

The impact of CSR on firm valuation is subject to controversies. The traditional, but challenged, approach stems from neoclassical theory, which argues that being ethical and taking positive externality problems into account generates additional costs (Palmer et al., 1995; Walley and Whitehead, 1994). In a competitive environment, firms that support higher costs are supposed to be overwhelmed by less ethical but also less constrained ones. Baumol (1991) notes that responsible behavior implies sacrificing profits. Thus, CSR is not consistent with maximizing shareholder value and, on competitive markets, unethical behavior should be supported by investors (Shleifer, 2004). This theoretical stream therefore postulates a negative relationship between CSR practices and shareholder value. 
On the other hand, investing in CSR might also provide financial benefits. Reducing waste, for instance, is a way to avoid environmental disasters, financial lawsuits, consumer boycotts and also to reduce costs. CSR business benefits are broad: an increase in brand value and reputation, higher motivation among employees, customer attraction and retention. According to Orlitzky et al. (2003), instrumental stakeholder theory supported by Freeman (1984) or Donaldson and Preston (1995) assumes a positive relationship between social responsibility and firm value. By satisfying stakeholders, the organization is more efficient and acquires a greater reputation. These positive attributes or moral capital generate "insurance-like" benefits (Godfrey et al., 2009), which preserve shareholder value in case of negative events and create goodwill.

Weber (2008) proposes what could be characterized as a financially "agnostic" approach. She argues that financial implications of doing good are mixed. Being socially responsible is profitable for a firm if the financial benefits from this behavior are higher than its costs. To precisely measure the profitability of CSR behavior, a firm has to assess the financial costs and benefits of such a policy for each subsequent year and discount it. She defines monetary CSR value added as:

$$
\text { Monetary Value Added }=\sum_{n=1}^{\infty} \frac{B_{n}^{C S R}-C_{n}^{C S R}}{(1+i)^{n}}
$$

Where: $n$, number of periods; $B_{n}^{C S R}$, CSR benefits; $C_{n}^{C S R}$, CSR costs; and $i$, discount rate.

This approach expresses a clear relationship between CSR and firm value. The higher the difference between the benefits and costs implied by socially responsible policies, the higher the present value is. The link between CSR and firm value is therefore strongly theoretically grounded in a discounting marginal cash flows analysis. Moreover, one could wonder whether CSR involvement does not have an impact on the discount rate. Such a change would have an effect on overall corporate cash flows. Insofar as investors estimate that risk decreases when social behaviors are undertaken (Godfrey et al., 2009), the discount rate also decreases, and therefore firm value should rise.

From an extra-financial perspective, CSR might also be valued by some investors, even if behaving ethically is not financially rewarding. Some shareholders might seek socially responsible companies rather that high performance stocks. An ethical fad over CSR would cause socially responsible companies to be overvalued compared to their non-CSR counterparts. In this case, argued by Galema et al. (2008) or Burlacu et al. (2004), excess demand would translate into over pricing, i.e. an ethical goodwill or market premium.

\section{I.2. EMPIRICAL LITERATURE}

The bulk of empirical studies focus on the financial - CSR relationship, while the direct link between CSR performance and firm value is less widely studied. The main results seem to support the stakeholder theory and find that market valuation is positively related to corporate social responsibility (Galema et al., 2008). CSR practices are generally divided into three dimensions: environment, social and governance. The environmental dimension of CSR is focused on the impact of the business activity. This includes, for instance, energy and raw material consumption, recycling, and toxic emissions/waste. The social part deals with human rights, health and safety at the workplace, employee diversity, corporate philanthropy or community involvement. Governance is concerned with issues like shareholder rights and independence of the board. In this section, we review the literature that encompasses more 
precisely the environmental or the corporate governance part and finally the entire spectrum of $\mathrm{CSR}^{1}$. Table 1 summarizes the related literature.

\section{*** Insert Table 1 here ***}

Some empirical research is dedicated to the specific impact of eco-efficiency. Dowell et al. (2000) study a sample of 89 US firms from the S\&P 500 from 1994 to 1997. They divide the sample into three subgroups according to the level of environmental standards (local, US and stringent global standards). Their results show that firm valuation assessed by Tobin's $q$ is positively related to stringent environmental standards. Konar and Cohen (2001) show that poor environmental performance is negatively related to the intangible part of asset value, thanks to Tobin's $q$. Therefore, a reduction of waste emissions implies an increase of market value.

King and Lenox (2002) refine the preceding work and distinguish waste prevention that leads to financial gain from reduced pollution that does not. More recently, Guenster et al. (2010), using the Innovest Strategic Value Investor Database over the 1997-2004 period, find a positive relationship between market value and eco-efficiency. They also underline that the market does not incorporate environmental information immediately. Heal (2005) already asserted that "one robust result seems to be that superior environmental performance is correlated with high values for Tobin's $q$ ".

On the corporate governance side, Goncharov et al. (2006) show, with 61 German firms over the 2002-2003 period, that firms with a high compliance with the German Corporate Governance Code exhibit a higher market value, assessed by market price. Beiner et al. (2006) also find that firm value measured by Tobin's $q$ is positively related to a high corporate governance level with a sample of 109 Swiss firms in 2002.

More broadly, Bird et al. (2007) examine the relationship between financial performance and CSR variables. Using KLD Research data on companies of the S\&P 500 index between 1991 and 2003, they assess the impact of five different dimensions of CSR: community, diversity, employee relations, environment and product. Each activity is scored positively (strengths) and negatively (concerns). For instance, employee relations are scored positively for profit sharing, good retirement benefits or safety records, whereas poor relations with unions are scored negatively. Bird et al. (2007) show that valuation multiples are positively related to diversity, employee and product strengths, and negatively to employee concerns. Furthermore, the authors interpret the negative effect of community strengths on firm valuation as a market penalty for excessive spending on philanthropic activities.

Galema et al. (2008) use the logarithm of book-to-market value as the dependent variable on data from KLD universe (mainly US firms) over the 1992-2006 period. Following Bird et al. (2007), diversity and environment prove to be positively related to market valuation, whereas governance is negatively related. On the other hand, community and employee relations do not have a significant effect, and do not seem to have an impact on stock pricing, as well the overall score, than the strength and concern decomposition.

Through using numerous samples and econometric refinements, these recent empirical studies reveal several limitations. First, the results seem to be the most conclusive for the environmental and diversity side of corporate social responsibility, but still challenged concerning the remaining dimensions. Second, Bird et al. (2007) and Galema et al. (2008) use

\footnotetext{
${ }^{1}$ To our knowledge, no study to date analyzes the impact of the social dimension alone on firm value.
} 
KLD data that mainly covers the US stock market and these measures ${ }^{2}$ can be challenged (Chatterji and Levine, 2006). Checking the results with another CSR database could therefore contribute other insights on the topic. Third, the methodology used is questionable. Some studies fail to take into account major controlling factors such as the industry. In order to overcome these flaws and expand prior contributions, we use a rich alternative dataset (MSCI ESG Data) on a worldwide basis and control the methodology by a large spectrum of control variables (i.e. industry, region, year, R\&D expenses). Our results prove to be challenging for the existing literature since they suggest findings opposite to prior evidence.

\section{DATA}

This section describes the data and methodology used to empirically investigate the link between corporate social responsibility and equity asset valuation. CSR data on firms is taken from MSCI ESG Data ${ }^{3}$. ESG are the three main proxy dimensions of corporate social responsibility: environment, social and governance. Financial data come from the FactSet database.

\section{II.1. MSCI ESG DATA}

Assessing corporate social responsibility is a difficult task. While financial reports are highly standardized, extra-financial information is often seen as a way to improve the reputation of companies. CSR data is therefore both opportunistically revealed and not exhaustive in company reports. Extra-financial information is provided by companies such as KLD or MSCI ESG Data. While KLD is the most widely used academic dataset, MSCI ESG Data offers an interesting alternative, which has been used in prior studies by Derwall et al. (2005), Guenster et al. (2010) or Aktas and DeBodt (2011). As mentioned by Guenster et al. (2010) the comprehensiveness of this database is one of its strengths. The rating methodology relies on data collected from various documents (corporate documents, government data, journals, relevant organizations and professionals) as well as an interview of the company. Overall, more than 120 datapoints are aggregated to assess the level of CSR compared to industry peers (i.e. "best-in-class" rating).

The rating process relies on the following four pillars: strategic governance, human capital, environment and stakeholder capital (see Figure 1). Environment refers to the way firms try to minimize their impact on nature in doing business and is the most studied relationship. Guenster et al. (2010) and Sinkin et al. (2008) both use the term "eco-efficiency" to define this "nature-sustainable" development. The social theme of ESG is divided into two components. Human capital deals mainly with relationships inside the firm, between the firm and its employees, whereas stakeholder capital is concerned with stakeholders and communities. Strategic governance is particularly focused on the treatment of shareholders and agency problems like conflicts of interest. The global CSR rating, named Intangible Value Assessment rating (henceforth IVA) by MSCI ESG Data is obtained by the aggregation of these four pillars.

\footnotetext{
${ }^{2}$ For Chatterji and Levine (2006) "KLD uses largely qualitative and subjective measures, which make it difficult to produce comparable and reliable metrics". MSCI ESG data is a measure which relies on extra-financial data mainly from corporate documents and interviews of the company, which are converted into datapoints. The ratings, however, are greatly influenced by MSCI ESG analysts who assess the key issues of each industry. Therefore, the MSCI ESG measures can also be seen as subjective. This is however another focus than the widely used KLD database, and a valuable complementary insight.

${ }^{3}$ Formerly known as Innovest Strategic Value Advisors and RiskMetrics.
} 
Each pillar is rated based on intermediate factors, scored on a scale from 0 to 10 . They are listed in figure 1. These factors aggregate the datapoints collected by MSCI. The methodology, however, cannot be reduced to pure quantitative scoring since MSCI ESG analysts play a significant role in the CSR assessment process by weighting the key issues for each industry. On the aggregate scores, the factors are not equally weighted. MSCI ESG analysts consider the main opportunities and risk for each industry and overweight these key factors. For instance, carbon dioxide emissions are more crucial for the basic materials industry than for the financial industry. Overall, the major CSR key issues for each industry are highly overweighted and contribute to approximately 80 percent of the final best-in-class rating.

This IVA rating is scored from AAA (best-in-class) to CCC (worst-in-class). The AAA to CCC aggregated IVA ratings have been converted into seven numerical scores, from 1 (lowest ranked) to 7 (highest ranked). We also use the four pillar scores (between 0 and 10), which enable us to precisely understand the impact of environment, human capital, strategic governance and stakeholder capital scores on firm valuation. Table 2 shows some statistics for IVA and its four subscores. According the MSCI methodology, the median IVA rating is equal to 4 . Furthermore, the environmental pillar exhibits the lowest median and mean and it is the only score that does not reach the maximum of 10 .

*** Insert Table 2 here ***

The coverage universe of MSCI ESG data is wide and includes companies from MSCI World (1,500 companies of developed markets, as defined by Morgan Stanley Capital International), MSCI Emerging Markets (200 companies), ASX 200 (200 companies from Australia) and FTSE 350 (275 British companies). Since the data before 2005 involves a small sample and ratings are mainly updated annually, we use annual data from 2005 to 2009. This represents 10,285 ratings concerning 2,838 different firms over a wide range of 50 countries (see table 3 for a complete description).

$$
\text { *** Insert Table } 3 \text { here *** }
$$

\section{II.2. FINANCIAL DATA}

We matched ESG with financial data. Financial data consists in valuation proxies (dependent variables) and control (independent) variables from FactSet. Tobin's $q$ and priceto-book ratio $(\mathrm{P} / \mathrm{B}$, also referred to as market-to-book) are both used to proxy asset equity valuation. Tobin's $q$ is popular among academics while $\mathrm{P} / \mathrm{B}$ is mostly used by asset management practitioners. Both metrics assess the value of stocks and are often even confused (Dam, 2008), the price-to-book ratio being used as a proxy of Tobin's $q$.

Tobin (1969) defines $q$ as the market value (MV) of assets divided by their book value (BV). We proxy the market value of assets as the book value of assets plus the market value of common stock less book value of common stock. Total assets are used as book value of assets. This simplified definition of Tobin' $q$ is close to the one also used in recent research articles $^{4}$ (Kaplan and Zingales, 1997; Drobetz et al., 2004; Guenster et al., 2010). P/B ratio is defined as stock price (market value of shareholder equity) divided by the book value of shareholder equity per stock. This ratio is often used by value portfolio managers to assess

\footnotetext{
${ }^{4}$ We simplify Guenster et al. (2010) formula by excluding balance sheet deferred taxes. Other proxies for Tobin's $q$, used by Chung and Pruitt (1994), lead to the same results.
} 
stock valuation. This is an interesting alternative to measure stock value that strongly correlates (Godfrey et al., 2009).

We devoted particular care to the model's specification by using a complete set of control variables. Since firm value is influenced by firm profitability, firm size, sales growth (Hirsh, 1991) and research and development expenses (McWilliams and Siegel, 2001, Dowell et al., 2000; King and Lenox, 2002; Konar and Cohen, 2001), we control for these variables. Firm profitability is measured by Return on Equity (RoE); firm size is defined as a logarithm of market capitalization ${ }^{5}$; sales growth as two-year revenue growth; R\&D is computed as research and development expenses divided by total assets ${ }^{6}$ (Guenster et al., 2010). Table 4 shows summary statistics for financial data.

*** Insert Table 4 here $* * *$

\section{EMPIRICAL ANALYSIS}

\section{III.1. FIRM VALUE AND CSR PRACTICES}

The correlation matrix (Table 5) shows that CSR variables are strongly and significantly correlated. The global ESG rating (IVA rating) is not significantly correlated with both valuation proxies (Tobin's $q$ and price-to-book). However, the human capital subscore exhibits a significant positive correlation with both valuation proxies, whereas the significant correlation is negative for the environmental pillar. Moreover, return on equity and firm size are positively related to IVA rating.

\section{*** Insert Table 5 here $* * *$}

We use cross-section data since variation in ratings, and therefore firm-specific fixed effects, are limited (Guenster et al., 2010) ${ }^{7}$. We control for years, industry and world regions thanks to dummy variables. The industries are coded according to Dow Jones industries level 1. Observations, broken down by industries, years and regions, are presented in table 6 .

$$
\text { *** Insert Table } 6 \text { here *** }
$$

Based on ordinary least squares, we estimate the following model with different proxies for value (Tobin's $q$ and price-to-book) and metrics. Following Guenster et al. (2010), dependent variables are measured in level, in logs and trimmed to ensure a limited effect of outliers. The trimming procedure allows us to drop potential outliers in the extreme left and right 0.5 percent of the distribution.

$$
\begin{gathered}
\text { Value }_{i}=\beta_{0}+\beta_{1} \text { CSR Rating }_{i}+\beta_{2} \text { RoE }_{i}+\beta_{3} \text { Size }_{i}+\beta_{4} \text { Sales growth }_{i}+ \\
\sum_{j=1}^{9} \gamma_{j} \text { Industry }_{i, j}+\sum_{j=1}^{4} \delta_{j} \text { Year }_{i, j}+\sum_{j=1}^{3} \rho_{j} \text { Region }_{i, j}+\varepsilon_{i}
\end{gathered}
$$

Where: Value $i$, valuation proxy for observation $i$; CSR Rating, proxy for CSR level; RoE $E_{i}$, Return on Equity; Size $e_{i}$ logarithm of market capitalization; Sales growth, two-year revenue

\footnotetext{
${ }^{5}$ We use financial data converted in USD with a variable exchange rate over the period.

${ }^{6}$ McWilliams and Siegel (2000) show that after inclusion of R\&D expenses in the model's specifications, corporate social efficiency has no impact on accounting performance.

${ }^{7}$ As mentioned by Guenster et al. (2010), a pooled model that enables fixed effects and time specific events is not possible because of the limited time variation in the CSR measures.
} 
growth; Industry ${ }_{i, j}$, dummy variable for industry set $j ;$ Year $_{i, j}$, dummy variable for year $j$; Region $_{i, j}$, dummy variable for region $j$; $\varepsilon_{i}$, residual.

Table 7 shows results for 2005-2009. These results are interesting since they rely on a wide unbalanced panel sample of almost 9,000 observations and exhibit an adjusted Rsquared between 0.209 and 0.359 . The variable used to proxy CSR (IVA rating) is highly significant $(\mathrm{p}<0.01)$ for each of the six dependent variables: Tobin's $q$ and price-to-book in level, logs and trimmed. The sign of the coefficients appears to be negative. The higher the degree of CSR, the lower the stock value of the firm. For two comparable firms, the most virtuous one is also the cheapest on financial markets. More precisely, a one-step increase in the IVA rating decreases ceteris paribus Tobin's $q$ by 0.03 and price-to-book by more than 0.18 . From the investor standpoint, this negative coefficient shows that CSR value added as defined by Weber (2008) is negative. Furthermore, the impact of CSR measured by IVA rating appears to be non-linear. Taking into account the logs of Tobin's $q$ and price-to-book significantly increases the R-squared. The latter rises from 0.212 to 0.328 for Tobin's $q$ and from 0.282 to 0.358 for price-to-book.

\section{*** Insert Table 7 here ***}

These results are obtained while controlling for a wide set of financial and nonfinancial variables. According to previous evidence, we find a highly positive and significant relationship between value and firm profitability proxied by RoE. Size is also positively related to firm value ${ }^{8}$. Concerning industry dummies, we find a positive industry premium for the following industries: Consumer (Non-Cyclical), Healthcare, Consumer (Cyclical) and Technology. On the other hand, the financial industry suffers from significant misevaluation. Dummies for years point to the drastic negative effect of the subprime-mortgage crisis on firm value in 2008. Asia appears to be the cheapest region in the world. These effects (industry, year and region), controlled together, are rarely introduced in previous studies and allow us to capture risk-premium differences.

\section{*** Insert Table 8 here $* * *$}

The whole CSR spectrum is sometimes seen as an overall vague, "all embracing" (van Marrewijk, 2003) notion and might hide significant differences between the subsets. Therefore, we substitute IVA rating in equation 2 by its four subscores: environment, human capital, strategic governance and stakeholder capital. This allows us to capture more specific sides of CSR that might have different weights from the investor's standpoint. Table 8 indicates that the results on the overall CSR rating are mainly driven by the environmental subscore. This pillar is significantly and negatively related to valuation proxies. The relations with strategic governance and stakeholder capital appear to be inconclusive, while human capital exhibits a positive correlation. Investors seem to value CSR subsets differently, in favor of the firms' human capital investments and not only diversity (Bird et al., 2007; Galema et al., 2008), whereas they sanction environmental involvement. The results seem to be very clear and robust concerning the influence of the environmental involvement of firms ( $p<0.01$ for all independent variables), whereas the impact of human capital is not so obvious. The relationship between valuation and human capital proves to be highly significant with Tobin's $q$ and its derivatives ( $\mathrm{p}<0.01$ ), but the influence on the price-to-book seems to be less robust, depending on the independent variable used.

\footnotetext{
${ }^{8}$ We observe no growth effect, as measured by two-year sales growth. Since the coefficients are close to zero and non-significant, the variable was removed from the regressions. The results are not significantly affected by this variable.
} 


\section{III.2. ROBUSTNESS CHECKS}

Robustness checks consist in extending the model's specifications by adding additional variables. Following McWilliams and Siegel (2001), we verify that R\&D expenses do not alter the results, since R\&D and CSR level are correlated. The authors show that adding such a variable to the model's specifications leads to the non-significance of CSR proxies. In order to simplify the presentation, the dependent variables are only taken in logs, as in Galema et al. (2008). Tables 9 and 10 exhibit the estimates for level-dependent variables, with $R \& D$ and $R \& D$ by sales growth as in Guenster et al. (2010). R\&D relates positively and significantly to firm value.

$$
\begin{aligned}
& \text { Value }_{i}=\beta_{0}+\beta_{1} \text { CSR Rating }_{i}+\beta_{2} \text { RoE }_{i}+\beta_{3} \text { Size }_{i}+\beta_{4} \text { Sales growth }_{i}+ \\
& \sum_{j=1}^{9} \gamma_{j} \text { Industry }_{i, j}+\sum_{j=1}^{4} \delta_{j} \text { Year }_{i, j}+\sum_{j=1}^{3} \rho_{j} \text { Region }_{i, j}+ \\
& \theta_{1} R \& D_{i}+\theta_{2}\left(R \& D \times \text { Sales growth }{ }_{i}\right)+\varepsilon_{i}
\end{aligned}
$$

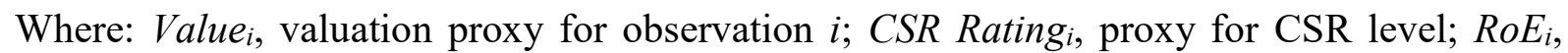
Return on Equity; Size $e_{i}$, logarithm of market capitalization; Sales growth, two-year revenue growth; Industry $i_{i, j}$, dummy variable for industry set $j ;$ Year $_{i, j}$, dummy variable for year $j$; Region $_{i, j}$, dummy variable for region $j ; R \& D_{i}$, research and development expenses divided by total assets; $R \& D \times$ Sales growth, , research and development expenses (divided by total assets) multiplied by two-year revenue growth; $\varepsilon_{i}$, residual.

$$
\begin{aligned}
& * * * \text { Insert Table } 9 \text { here } * * * \\
& * * * \text { Insert Table } 10 \text { here } * * *
\end{aligned}
$$

Globally, the signs of coefficients on IVA rating are not affected by this new specification and significance persists after controlling for both variables. Similarly, the negative relationship between market valuation and the environmental subset is still highly significant $^{9}(\mathrm{p}<0.01)$. The link between value and human capital, however, is weaker for Tobin's $q$ variable and no longer significant for price-to-book. This finding confirms the previous results that the link between market valuation and human capital is sensitive to the model's specification. As discussed by McWilliams and Siegel (2001), R\&D seems to capture part of CSR practices, and especially its human capital side. Finally, complementary tests adding sales growth, capital structure (Debt to shareholders' equity ratio), or risk (Beta) as independent variables, do not alter the results.

\section{III.3. DISCUSSION}

Contrary to the mainstream of empirical related research, we find that high CSR involvement, and particularly eco-efficiency, is not rewarded by shareholders. This calls into question the ethical goodwill reported by Galema et al. (2008) or Bird et al. (2007). Two main reasons could explain this divergence. First, we use a CSR dataset other than KLD. As mentioned by Chatterji and Levine (2006), subjective measures create noise in CSR assessment. If MSCI ESG data also has a subjective part in the assessment of key issues for each sector, the process relies on a large set of datapoints and might offer another focus on CSR. This does not, however, explain the opposite findings of Guenster et al. (2010) with the

\footnotetext{
${ }^{9}$ As a subset of CSR proxy we also use the EcoValue 21 rating, created by Innovest Strategic Value Advisors. This proxy measures eco-efficiency (Guenster et al. 2010) insofar as a firm's environmental responsibility is assessed. Derwall et al. (2005) and Guenster et al. (2010) also use this rating. It does not alter our results.
} 
same data provider for the environment pillar. Their study, nevertheless, was performed over the 1997-2004 period whereas ours begins in 2005 and, therefore, includes a larger set of companies. Our results seem to support the idea that perceptions of environmental involvement have changed over time.

This CSR discount could be explained different ways. According to a first hypothesis, investors rationally assess the marginal costs and benefits of CSR and find negative monetary value added. From their standpoint, being a socially responsible firm means spending money, especially on greenwashing, to the detriment of the stockholder's best interests. According to this view, theoretically supported by Friedman (1962), Levitt (1958) or Shleifer (2004), there is a conflict of interest between maximizing shareholder wealth and positive externalities. This leads to a sanction by shareholders, who underprice environmentally involved firms. According to a second hypothesis, myopic investors are not aware of the long-term potential benefits that may arise from a high level of environmentally friendly practices. They merely overweight the actual costs and have trouble forecasting future positive related cash flows or do not adjust the discount rate properly, compared to the insurance-like CSR benefits (Godfrey et al., 2009).

The results of this study have managerial implications for both corporate and portfolio managers. Corporate managers must be aware that CSR involvement is not rewarded by shareholders in firm valuation, and even punished. Shareholders, as firm owners, do not seem to understand the benefits of dispersing value among the stakeholders involved. Only investments inside the firm in human capital appear to be positively perceived. On the environmental side, which is the most popular subset, the corporate manager has to make a trade-off between positive externalities and shareholders. If the latter feel excluded from value allocation, the penalty for this misalignment of interests is the firm's underpricing on the market. These results also have managerial implications for value style investors. From a "buy cheap, sell dear" point of view, the firm's CSR policy has an impact on market discount. Since an active value investor buys under-valuated stock, he has to take the eventual badwill resulting from a high level of environmental efforts into account.

\section{CONCLUSION}

In this paper, we investigate the precise relationship between CSR and the market valuation of firms. Firms with a high level of CSR may suffer from higher cost due to additional constraints. However, such behavior may also be financially rewarding for the firm, through the "insurance-like benefit" (Godfrey et al., 2009) of a greater reputation. We adopt an agnostic approach to this research question by conducting an empirical analysis based on a rich and informative dataset. We use MSCI ESG reference ratings and subscores in order to proxy the CSR behavior of firms and FactSet for financial data. In order to ensure the robustness of the results, the models use a large set of control variables: financial performance, size, growth and dummy variables for industries, years and regions.

Our study, which includes nearly 9,000 worldwide observations from 2005 to 2009, exhibits challenging results. While the bulk of academic empirical work reports a positive relationship between CSR performance and firm value, we clearly find a negative effect, supporting the trade-off hypothesis between shareholder and the other stakeholders. More precisely, the environmental subscore has a strong negative impact on firm value. These findings are not widely affected by a change in the dependent variable for firm value and the addition of supplementary control variables ( $R \& D$ and $R \& D$ by sales growth). While human 
capital is positively related to stock valuation, results seem to be contingent on model specifications. This issue is left for future research.

Shareholders therefore seem to consider that CSR costs, and more precisely environmental costs, exceed benefits from the firm's standpoint. Positive externalities from the enhancement of satisfaction of various stakeholders are not enough to compensate in the equity asset valuation process and leads to underpricing. The market discount stemming from CSR behavior challenges the results of prior studies (Galema, 2008; Bird et al., 2007; Guenster et al., 2010) and further evidence is required based on diverse CSR databases, to confirm the reliability of the measures, and obtained with particular attention to model specifications.

\section{Acknowledgements}

This research results from a partnership between the Universite d'Auvergne and the French asset management company Metropole Gestion. We are grateful to Corinne Baudoin, Isabel Levy and François-Marie Wojcik for their support. We would like to thank the two anonymous reviewers for their valuable comments, Pierre Cholet, Philippe Gillet, Xavier Hollandts, Cédric Lesage, Yves Mard, Bernard Raffournier, Christophe Revelli and the participants in the CRCGM workshop, AFFI 2011 and CIGE 2011 international conferences. We wish to thank MSCI ESG Data for providing ESG Data. The ideas, methodology and findings expressed in this paper are the sole responsibility of the authors.

\section{References}

AkTAs, N., DE Bodt, E., Cousin, J.-G.., 2011, "Do financial markets care about SRI? Evidence from mergers and acquisitions" Journal of Banking \& Finance, 35(7), 1753-1761.

BAUMOL, W., 1991, Perfect Markets and Easy Virtue: Business Ethics and the Invisible Hand, Basil Blackwell, Oxford.

Beiner, S., Drobetz, W., Schmid, M. M., Zimmermann, H., 2006, “An Integrated Framework of Corporate Governance and Firm Valuation", European Financial Management, 12(2), 249-283.

Bird, R. Hall, A.D., Momente, F., Reggiani, F., 2007, "What Corporate Social Responsibility Activities are Valued by the Market?", Journal of Business Ethics, 76, 189206.

Bowen, H.R., 1953, The Social Responsibility of the Businessman, New York, Harper and Row.

Burlacu, R., GiRERd-Potin, I., DuPRe, D., 2004, "Y a-t-il un sacrifice à être éthique ? Une étude de performance des fonds socialement responsables américains", Banque et Marchés, $69,20-27$.

ChatterJ, A. K., Levine, D. I., 2006, "Breaking Down the Wall of Codes: Evaluating NonFinancial Performance Measurement”, California Management Review, 48(2), 29-51.

Chung, K.H., PruitT, S.W. 1994, “A Simple Approximation of Tobin's q", Financial Management (autumn), 70-74. 
DAHLSRUD, A., 2008, "How corporate social responsibility is defined: an analysis of 37 definitions", Corporate Social Responsibility and Environmental Management, 15, 1-13.

DAM, L., 2008, Corporate Social Responsibility and Financial Markets, PhD thesis, University of Groningen.

Derwall, J., Guenster, N., BAuer, R., KoediJK, K., 2005, “The eco-efficiency premium puzzle”, Financial Analysts Journal, 61, 51-63.

DonaldSON, T., PRESTON, L.E., 1995, "The stakeholder theory of the corporation: Concepts, evidence, and implications", Academy of Management Review, 20, 65-91.

Dowell, G. A., Hart, S. AND Yeung, B., 2000, "Do corporate global environmental standards create or destroy market value?”, Management Science, 46(8), 1059-74.

Drobetz,W., Schillhofer, A. AND ZimmermanN, H., 2004, "Corporate governance and expected stock returns: evidence from Germany", European Financial Management, 10, 26793.

Dupre, D., Girerd-Potin, I., Jimenez-Garces, S., Louvet, P., 2006, "Les investisseurs paient pour l'éthique. Conviction ou prudence ?", Banque et Marchés, 84, 45-59.

FreEMAN, R. E., 1984, Strategic management: A stakeholder approach, Marshfield, Pitman.

Friedman, M., 1962, Capitalism and Freedom, University of Chicago Press, Chicago.

Galema, R., Plantinga, A., Scholtens, B., 2008, "The stocks at stake: Return and risk in socially responsible investment", Journal of Banking and Finance, 32(12), 2646-2654

Godfrey, P.C., Merrill, C.B., AND Hansen, J.M., 2009, "The relationship between corporate social responsibility and shareholder value: An empirical test of the risk management hypothesis", Strategic Management Journal, 30, 425-445.

Goncharov, I., Werner, J. R., \& Zimmermann, J., 2006, "Does Compliance with the German Corporate Governance Code Have an Impact on Stock Valuation? An empirical analysis", Corporate Governance: An International Review, 14(5), 432-445.

Guenster, N., Bauer, R., Derwall, J., Koedijk, K., 2010, "The Economic Value of Corporate Eco-Efficiency", European Financial Management, 26pp.

Hamilton, S., Jo, H., Statman, M., 1993, "Doing well while doing good? The investment performance of socially responsible mutual funds", Financial Analysis Journal, NovemberDecember, 62-65.

HeAL, G. M., 2005, “Corporate social responsibility? An economic and financial framework", Geneva Papers on Risk and Insurance: Issues and Practice, 30, 387-409.

HORVÁTHOVÁ, E., 2010, "Does environmental performance affect financial performance? A meta-analysis", Ecological Economics, 70, 52-59.

KING, A. AND LENOX, M., 2002, "Exploring the locus of profitable pollution reduction", Management Science, 48(2), 289-99.

KonAR, S. AND COHEN, M. A., 2001, "Does the market value environmental performance?", Review of Economics and Statistics, 83(2), 281-89.

LevitT, T., 1958, “The Dangers of Social Responsibility”, Harvard Business Review, 36(5), 41-50.

VAN MARREWIJK, M., 2003, "Concepts and Definitions of CSR and Corporate Sustainability: Between Agency and Communion”, Journal of Business Ethics, 44 (2-3), 95-105. 
Margolis, J. D., Walsh, J. P., 2001, People and profits? The search for a link between a company's social and financial performance, Mahwah, Erlbaum.

MCWilliams, A., Siegel, D., 2000, "Corporate social responsibility and financial performance: correlation or misspecification?”, Strategic Management Journal, 21, 603-609.

MCWilliams, A., Siegel, D., 2001, "Corporate social responsibility: a theory of the firm perspective”, Academy of Management Review, 26 (1), 117-127.

OrlitzKy, M., SchMidT, F. L., RYNES, S. L, 2003, "Corporate social and financial performance: A meta-analysis”, Organization Studies, 24(3), 403-441.

Palmer, K., OAtes, W.E., Portey, P.R., 1995, “Tightening environmental standards: the benefit-cost or the no-cost paradigm?", Journal of Economic Perspectives, 9 (4), 119-132.

RenNeboog, L.D.R., Horst, J.R. TER, ZHANG, C., 2007. "The Price of Ethics: Evidence from Socially Responsible Mutual Funds”, Discussion Paper 2007-012, Tilburg University, Tilburg Law and Economic Center.

ShlEIFER, A., 2004, "Does competition destroy ethical behavior?", American Economic Association Papers and Proceedings, 94 (2), 414-418.

Sinkin, C., Wright C. J., BuRnetT R. D., 2008, "Eco-efficiency and firm value”, Journal of Accounting and Public Policy, 27 (2),167-176

ToBIN, J., 1969, “A general equilibrium approach to monetary theory", Journal of Money Credit and Banking, 1 (1), 15-29.

Walley, N., Whitehead, B., 1994, "It's not easy being green”, Harvard Business Review, 4652.

WEBER, M., 2008, "The business case for corporate social responsibility: A company-level measurement approach for CSR", European Management Journal, 26, 247- 261. 


\section{Tables and figures}

Figure 1: The four pillars of IVA

\section{Strategic Governance}

Strategy

Agility/adaptation

Traditional governance concerns

Intellectual capital

Product safety

\section{Human Capital}

Workplace practices, including recruitment \& retention

Labor relations

Health \& safety

Effective waste management \& reduction

Climate risk assessment

New product development

\section{Stakeholder Capital}

Partnerships with stakeholders

Relationships with host communities

Management of supply chains

Emerging market strategies

Operations at risk of human rights abuses

\section{Environment}

Risk management systems, including board \& management oversight

Disclosure/verification

Efficient use of resources

Source: MSCI ESG Research - Intangible Value Assessment (IVA) Methodology 
Table 1: Empirical review synthesis

\begin{tabular}{|c|c|c|c|c|c|}
\hline Article & Sample & $\begin{array}{l}\text { Proxy for } \\
\text { valuation }\end{array}$ & Proxy for CSR & Main control variables & Main results \\
\hline $\begin{array}{l}\text { Dowell et al. } \\
(2000)\end{array}$ & $\begin{array}{l}89 \text { US firms from } \\
\text { the S\&P } 500 \text { from } \\
1994 \text { to } 1997\end{array}$ & Tobin's $q$ & $\begin{array}{l}\text { Dummies for level of environmental } \\
\text { standards (Investor Responsibility } \\
\text { Research Center's, IRRC) }\end{array}$ & $\begin{array}{l}\text { R\&D intensity, advertising } \\
\text { intensity, leverage, } \\
\text { multinationality, firm size }\end{array}$ & $\begin{array}{l}\text { More stringent environmental } \\
\text { standards are positively related } \\
\text { with firm value }\end{array}$ \\
\hline $\begin{array}{l}\text { Konar and } \\
\text { Cohen }(2001)\end{array}$ & $\begin{array}{l}321 \text { firms of the } \\
\text { S\&P 500, } 1989\end{array}$ & Tobin's $q$ & $\begin{array}{l}\text { Toxic chemicals emitted per dollar } \\
\text { revenue of the firm, number of } \\
\text { environmental lawsuits pending against } \\
\text { the firm (Investor Responsibility Research } \\
\text { Center, 1993) }\end{array}$ & $\begin{array}{l}\text { R\&D expenditures, market share, } \\
\text { industry concentration, firm } \\
\text { growth rates and advertising } \\
\text { expenditures }\end{array}$ & $\begin{array}{l}\text { Intangible asset value is } \\
\text { negatively linked with poor } \\
\text { environmental performance }\end{array}$ \\
\hline $\begin{array}{l}\text { King and } \\
\text { Lenox (2002) }\end{array}$ & $\begin{array}{l}614 \text { US firms, } \\
1991-1996\end{array}$ & Tobin's $q$ & $\begin{array}{l}\text { Total toxicity weighted emissions, } \\
\text { measure of waste treatment (Toxic } \\
\text { Release Inventory, TRI) }\end{array}$ & $\begin{array}{l}\text { Size, growth, capital intensity, } \\
\text { leverage, R\&D intensity, rational } \\
\text { wages, regulatory stringency, } \\
\text { permits }\end{array}$ & $\begin{array}{l}\text { Firm value is negatively related } \\
\text { to the level of toxic emission }\end{array}$ \\
\hline $\begin{array}{l}\text { Beiner et al. } \\
(2006)\end{array}$ & $\begin{array}{l}109 \text { Swiss firms, } \\
2002\end{array}$ & Tobin's $q$ & $\begin{array}{l}\text { Corporate governance index based on a } \\
\text { survey }\end{array}$ & $\begin{array}{l}\text { Beta, age, industry, CEO } \\
\text { characteristics, size, ROA, age, } \\
\text { SMI inclusion, growth, ownership } \\
\text { variable, standard deviation of } \\
\text { stock returns, intangible assets }\end{array}$ & $\begin{array}{l}\text { Firm value is positively related to } \\
\text { high corporate governance level }\end{array}$ \\
\hline $\begin{array}{l}\text { Bird et al. } \\
(2007)\end{array}$ & $\begin{array}{l}\text { KLD Research } \\
\text { data on companies } \\
\text { of the S\&P 500, } \\
\text { from } 1991 \text { to } 2003\end{array}$ & $\begin{array}{l}\text { Market-to-book } \\
\text { value, Price-to- } \\
\text { earnings }\end{array}$ & KLD CSR ratings & $\begin{array}{l}\text { Size, momentum, leverage, } \\
\text { industry }\end{array}$ & $\begin{array}{l}\text { Valuation multiples are } \\
\text { positively related to diversity, } \\
\text { employee and product strengths, } \\
\text { and negatively to employee } \\
\text { concerns }\end{array}$ \\
\hline $\begin{array}{l}\text { Galema et al. } \\
\text { (2008) }\end{array}$ & $\begin{array}{l}\text { KLD universe } \\
\text { (mainly US firms), } \\
\text { 1992-2006 period }\end{array}$ & $\begin{array}{l}\text { Log (Book-to- } \\
\text { market) }\end{array}$ & KLD CSR ratings & $\begin{array}{l}\text { R\&D intensity, R\&D missing, } \\
\text { dummy for stocks belonging to the } \\
\text { Russell } 3000 \text {, firm age, ROE, } \\
\text { dummy for time }\end{array}$ & $\begin{array}{l}\text { Diversity and environment prove } \\
\text { to be positively related to market } \\
\text { valuation, whereas governance is } \\
\text { negatively related. }\end{array}$ \\
\hline $\begin{array}{l}\text { Guenster et al. } \\
\text { (2010) }\end{array}$ & $\begin{array}{l}\text { Innovest Strategic } \\
\text { Value Investor } \\
\text { Database, US } \\
\text { stock market } \\
1997-2004 \text { period }\end{array}$ & Tobin's $q$ & $\begin{array}{l}\text { Eco-efficiency rating, Innovest Strategic } \\
\text { Value Investor Database }\end{array}$ & $\begin{array}{l}\text { Sales growth, firm age, size, ROA, } \\
\text { R\&D, R\&D*sales growth, Nasdaq } \\
\text { dummy }\end{array}$ & $\begin{array}{l}\text { A positive relationship between } \\
\text { market value and eco-efficiency }\end{array}$ \\
\hline
\end{tabular}


Table 2: Summary statistics for MSCI ESG Data ratings

\begin{tabular}{lccccccc}
\hline & Mean & Median & Max. & Min. & Std. Dev. & Skewness & Kurtosis \\
\hline IVA Rating & 3.781 & 4.000 & 7.000 & 1.000 & 1.718 & 0.181 & 2.199 \\
Strategic governance & 5.404 & 5.400 & 10.000 & 0.000 & 1.860 & -0.055 & 2.600 \\
Human capital & 5.495 & 5.500 & 10.000 & 0.000 & 1.670 & -0.125 & 2.914 \\
Environment & 4.890 & 4.999 & 9.810 & 0.000 & 1.685 & -0.105 & 2.613 \\
Stakeholder capital & 5.234 & 5.200 & 10.000 & 0.000 & 1.842 & -0.039 & 2.695 \\
\hline
\end{tabular}

Period: 2005-2009. Observations: 10,285 (2,838 firms). For the IVA rating, we convert letter scores into numerical scores with a linear scaling method: $\mathrm{AAA}=7$ (best score), $\mathrm{AA}=6, \mathrm{~A}=5, \mathrm{BBB}=4$ (industry median score), $\mathrm{BB}=3, \mathrm{~B}=2, \mathrm{CCC}=1$ (worst score).

There are not significant differences in the overall IVA rating between years. The $\mathrm{p}$-value for the corresponding Anova test is 0.7172 .

\section{Table 3: Number of firms by country}

\begin{tabular}{lc}
\hline Country & Number of firms \\
\hline United States of America & 834 \\
Japan & 365 \\
Great-Britain & 348 \\
Australia & 249 \\
Canada & 145 \\
France & 88 \\
Germany & 64 \\
Hong Kong & 59 \\
Italy & 56 \\
Spain & 49 \\
Switzerland & 48 \\
Sweden & 46 \\
China & 36 \\
Brazil & 33 \\
Netherlands & 32 \\
South Korea & 28 \\
Finland & 27 \\
India & 26 \\
Norway & 24 \\
Singapore & 24 \\
Denmark & 20 \\
\hline Austria, Belgium, Greece, & \\
Ireland, Malaysia, Mexico, New & \\
Zealand, Portugal, Russia, South & \\
Africa, Taiwan & \\
\hline Bermuda, Chile, Czech Republic, & Less than 10 \\
Egypt, Hungary, Indonesia, & \\
Israel, Luxembourg, Morocco, & \\
Pakistan, Peru, Philippines, & \\
Turkey, Venezuela & \\
\hline & \\
\hline
\end{tabular}


Table 4: Summary statistics for financial data

\begin{tabular}{lcccc}
\hline Variable & Mean & Median & Std. Dev. & Obs. \\
\hline Q & 1.680 & 1.322 & 1.126 & 9,514 \\
P/B & 3.154 & 1.988 & 7.973 & 8,990 \\
RoE & 0.159 & 0.133 & 0.576 & 8,991 \\
Size & 8.679 & 8.676 & 1.377 & 9,639 \\
R\&D & 0.035 & 0.018 & 0.047 & 4,033 \\
\hline
\end{tabular}

Period: 2005-2009. Where: Q, Tobin's q; P/B, price-to-book; RoE, Return on Equity; Size, logarithm of market capitalization (billion USD); R\&D, Research and development expenses scaled by total assets. 
Table 5: Correlation matrix

\begin{tabular}{|c|c|c|c|c|c|c|c|c|c|}
\hline $\begin{array}{l}\text { Sample size: } 8,923 \\
\text { Period: 2005-2009 }\end{array}$ & Q & $\mathrm{P} / \mathrm{B}$ & IVA & $\begin{array}{c}\text { Strategic } \\
\text { governance }\end{array}$ & $\begin{array}{l}\text { Human } \\
\text { capital }\end{array}$ & Environment & $\begin{array}{c}\text { Stakeholder } \\
\text { capital }\end{array}$ & RoE & Size \\
\hline $\mathrm{Q}$ & 1 & & & & & & & & \\
\hline $\mathrm{P} / \mathrm{B}$ & $0.3341 * * *$ & 1 & & & & & & & \\
\hline IVA & 0.0008 & -0.0157 & 1 & & & & & & \\
\hline Strategic governance & 0.0099 & 0.0087 & $0.7643 * * *$ & 1 & & & & & \\
\hline Human capital & $0.0494 * * *$ & $0.0191^{*}$ & $0.6757^{* * *}$ & $0.6335^{* * *}$ & 1 & & & & \\
\hline Environment & $-0.0357 * * *$ & $-0.0265^{* *}$ & $0.6791 * * *$ & $0.6553^{* * *}$ & $0.5211 * * *$ & 1 & & & \\
\hline Stakeholder capital & 0.0127 & -0.0034 & $0.7067^{* * *}$ & $0.6872 * * *$ & $0.6160 * * *$ & $0.5776^{* * *}$ & 1 & & \\
\hline $\mathrm{RoE}$ & $0.1881 * * *$ & $0.5168 * * *$ & $0.0257 * *$ & $0.0430 * * *$ & $0.0474 * * *$ & 0.0107 & $0.0393^{* * *}$ & 1 & \\
\hline Size & $0.1650^{* * *}$ & $0.0491 * * *$ & $0.2173^{* * *}$ & $0.1605 * * *$ & $0.1481^{* * *}$ & $0.2163^{* * *}$ & $0.2149 * * *$ & $0.0787 * * *$ & 1 \\
\hline
\end{tabular}

Period: 2005-2009. Where: Q, Tobin's q; P/B, price-to-book; IVA Rating: numerical variable from 1 (CCC) to 7 (AAA); Strategic governance, Human capital, Environment and Stakeholder capital, the four pillars' subscores; RoE, Return on Equity; Size, logarithm of market capitalization (billion USD). 
Table 6: Observations by industry, year and region

\begin{tabular}{lrr}
\hline & Observations & Percentage \\
\hline Energy & 555 & 5.4 \\
Basic Materials & 953 & 9.3 \\
Industrial & 1,955 & 19.0 \\
Consumer, Non-Cyclical & 729 & 7.1 \\
Healthcare & 633 & 6.2 \\
Consumer, Cyclical & 1,709 & 16.6 \\
Telecommunications & 346 & 3.4 \\
Utilities & 513 & 5.0 \\
Financial & 2,214 & 21.5 \\
Technology & 678 & 6.6 \\
\hline TOTAL & 10,285 & 100.0 \\
\hline Year 2005 & 1,266 & 12.3 \\
Year 2006 & 2,012 & 19.6 \\
Year 2007 & 2,188 & 21.3 \\
Year 2008 & 2,422 & 23.5 \\
Year 2009 & 2,397 & 23.3 \\
\hline TOTAL & 10,285 & 100.0 \\
\hline Asia & 2,058 & 20.0 \\
Europe & 3,424 & 33.3 \\
North America & 3,847 & 37.4 \\
Rest of the World & 956 & 9.3 \\
\hline ToTAL & 10,285 & 100.0 \\
\hline
\end{tabular}

The data that appears in italics is not used as dummies in the regressions. 
Table 7: Regressions with IVA rating

\begin{tabular}{|c|c|c|c|c|c|c|}
\hline & Q & $\log (\mathrm{Q})$ & Trimmed Q & $\mathrm{P} / \mathrm{B}$ & $\log (\mathrm{P} / \mathrm{B})$ & Trimmed $\mathrm{P} / \mathrm{B}$ \\
\hline \multirow[t]{2}{*}{ Intercept } & $0.89 * * *$ & $-0.07 * *$ & $0.87 * * *$ & $1.77 * * *$ & $-0.55 * * *$ & $0.61 * * *$ \\
\hline & $(9.95)$ & $(-2.06)$ & $(10.73)$ & $(2.80)$ & $(-9.37)$ & $(2.59)$ \\
\hline \multirow[t]{2}{*}{ IVA Rating } & $-0.03 * * *$ & $-0.02 * * *$ & $-0.03 * * *$ & $-0.18 * * *$ & $-0.03 * * *$ & $-0.09 * * *$ \\
\hline & $(-4.97)$ & $(-7.47)$ & $(-5.13)$ & $(-3.91)$ & $(-8.25)$ & $(-5.21)$ \\
\hline \multirow[t]{2}{*}{ RoE } & $0.27 * * *$ & $0.11 * * *$ & $0.24 * * *$ & $6.99 * * *$ & $0.36^{* * *}$ & $2.02 * * *$ \\
\hline & $(15.02)$ & $(16.68)$ & $(15.20)$ & $(55.65)$ & $(30.88)$ & $(28.56)$ \\
\hline \multirow[t]{2}{*}{ Size } & $0.13 * * *$ & $0.07 * * *$ & $0.13 * * *$ & 0.04 & $0.15^{* * *}$ & $0.25 * * *$ \\
\hline & $(15.25)$ & $(22.11)$ & $(15.71)$ & $(0.64)$ & $(26.60)$ & $(10.66)$ \\
\hline \multirow[t]{2}{*}{ Basic Materials } & 0.08 & 0.02 & 0.07 & 0.28 & $0.07 *$ & $0.25 *$ \\
\hline & $(1.50)$ & $(1.17)$ & $(1.35)$ & $(0.71)$ & $(1.81)$ & $(1.73)$ \\
\hline \multirow[t]{2}{*}{ Industrial } & 0.06 & 0.03 & 0.04 & $0.75 * *$ & $0.21 * * *$ & $0.60 * * *$ \\
\hline & $(1.13)$ & $(1.53)$ & $(0.82)$ & $(2.16)$ & $(6.47)$ & $(4.65)$ \\
\hline \multirow[t]{2}{*}{ Consumer, Non-Cyclical } & $0.28 * * *$ & $0.12 * * *$ & $0.27 * * *$ & $1.69 * * *$ & $0.34 * * *$ & $1.48 * * *$ \\
\hline & $(4.84)$ & $(5.54)$ & $(5.27)$ & $(4.17)$ & $(8.99)$ & $(9.87)$ \\
\hline \multirow[t]{2}{*}{ Healthcare } & $0.68 * * *$ & $0.30 * * *$ & $0.66 * * *$ & $2.37 * * *$ & $0.44 * * *$ & $1.31 * * *$ \\
\hline & $(11.44)$ & $(12.91)$ & $(12.21)$ & $(5.61)$ & $(11.25)$ & $(8.39)$ \\
\hline \multirow[t]{2}{*}{ Consumer, Cyclical } & $0.19 * * *$ & $0.05 * * *$ & $0.14 * * *$ & $1.10 * * *$ & $0.17 * * *$ & $0.79 * * *$ \\
\hline & $(3.77)$ & $(2.66)$ & $(3.04)$ & $(3.10)$ & $(5.02)$ & $(5.99)$ \\
\hline \multirow[t]{2}{*}{ Telecommunications } & -0.11 & $-0.05^{*}$ & -0.10 & $0.87^{*}$ & $0.12 * * *$ & $0.64 * * *$ \\
\hline & $(-1.53)$ & $(-1.81)$ & $(-1.62)$ & $(1.73)$ & $(2.60)$ & $(3.43)$ \\
\hline \multirow[t]{2}{*}{ Utilities } & $-0.36^{* * *}$ & $-0.18 * * *$ & $-0.36^{* * *}$ & -0.03 & -0.04 & -0.19 \\
\hline & $(-5.78)$ & $(-7.68)$ & $(-6.49)$ & $(-0.07)$ & $(-0.88)$ & $(-1.15)$ \\
\hline \multirow[t]{2}{*}{ Financial } & $-0.47 * * *$ & $-0.31 * * *$ & $-0.49 * * *$ & -0.15 & $-0.27 * * *$ & $-0.44 * * *$ \\
\hline & $(-9.80)$ & $(-16.44)$ & $(-11.09)$ & $(-0.44)$ & $(-8.56)$ & $(-3.44)$ \\
\hline \multirow[t]{2}{*}{ Technology } & $0.80 * * *$ & $0.32 * * *$ & $0.76 * * *$ & $2.33 * * *$ & $0.45 * * *$ & $1.58 * * *$ \\
\hline & $(13.63)$ & $(14.21)$ & $(14.19)$ & $(5.61)$ & $(11.67)$ & $(10.25)$ \\
\hline \multirow[t]{2}{*}{ Year 2005} & $0.15 * * *$ & $0.09 * * *$ & $0.16 * * *$ & $0.47 *$ & $0.28 * * *$ & $0.46 * * *$ \\
\hline & $(4.11)$ & $(6.83)$ & $(5.00)$ & $(1.89)$ & $(11.73)$ & $(4.90)$ \\
\hline \multirow[t]{2}{*}{ Year 2006} & $0.22 * * *$ & $0.13 * * *$ & $0.22 * * *$ & $0.57 * * *$ & $0.32 * * *$ & $0.61 * * *$ \\
\hline & $(7.21)$ & (10.98) & $(8.06)$ & $(2.64)$ & (15.69) & $(7.58)$ \\
\hline \multirow[t]{2}{*}{ Year 2007} & $0.16^{* * *}$ & $0.09 * * *$ & $0.17 * * *$ & $0.56 * * *$ & $0.21 * * *$ & $0.53 * * *$ \\
\hline & $(5.27)$ & $(7.40)$ & $(6.06)$ & $(2.59)$ & $(10.65)$ & $(6.61)$ \\
\hline \multirow[t]{2}{*}{ Year 2008} & $-0.23 * * *$ & $-0.13 * * *$ & $-0.20 * * *$ & $-0.73 * * *$ & $-0.24 * * *$ & $-0.46^{* * *}$ \\
\hline & $(-7.64)$ & $(-11.77)$ & $(-7.58)$ & $(-3.47)$ & $(-12.21)$ & $(-5.91)$ \\
\hline \multirow[t]{2}{*}{ Asia } & $-0.61 * * *$ & $-0.27 * * *$ & $-0.52 * * *$ & $-0.78 * * *$ & $-0.41 * * *$ & $-1.29 * * *$ \\
\hline & $(-14.97)$ & $(-17.11)$ & $(-14.18)$ & $(-2.70)$ & $(-15.32)$ & $(-12.01)$ \\
\hline \multirow[t]{2}{*}{ Europe } & $-0.40 * * *$ & $-0.15 * * *$ & $-0.33 * * *$ & -0.13 & $-0.13 * * *$ & $-0.56 * * *$ \\
\hline & $(-10.43)$ & $(-10.13)$ & $(-9.62)$ & $(-0.47)$ & $(-4.99)$ & $(-5.57)$ \\
\hline \multirow[t]{2}{*}{ North America } & $-0.36 * * *$ & $-0.13 * * *$ & $-0.28 * * *$ & -0.19 & $-0.12 * * *$ & $-0.54 * * *$ \\
\hline & $(-9.32)$ & $(-8.46)$ & $(-7.93)$ & $(-0.69)$ & $(-4.82)$ & $(-5.30)$ \\
\hline Sample size & 8938 & 8938 & 8893 & 8972 & 8972 & 8883 \\
\hline R-squared & 0.212 & 0.328 & 0.233 & 0.282 & 0.358 & 0.206 \\
\hline Adjusted $\mathrm{R}^{2}$ & 0.211 & 0.326 & 0.232 & 0.280 & 0.357 & 0.205 \\
\hline
\end{tabular}

Period: 2005-2009. Where: Q, Tobin's $q$; P/B, Price-to-Book; IVA Rating: numerical variable from 1 (CCC) to 7 (AAA); RoE, Return on Equity; Size, logarithm of market capitalization (billion USD); Basic Materials to Technology, dummy variables for the industry sets; Year 2005 to 2008, dummy variables for the corresponding years; Asia, Europe, and North America, dummy variables for the regions. 
Table 8: Regressions with subscores

\begin{tabular}{|c|c|c|c|c|c|c|}
\hline & $\mathrm{Q}$ & $\log (\mathrm{Q})$ & Trimmed Q & $\mathrm{P} / \mathrm{B}$ & $\log (\mathrm{P} / \mathrm{B})$ & Trimmed $\mathrm{P} / \mathrm{B}$ \\
\hline \multirow[t]{2}{*}{ Intercept } & $0.93 * * *$ & -0.06 & $0.91 * * *$ & $1.93 * * *$ & $-0.53 * * *$ & $0.65 * * *$ \\
\hline & $(10.13)$ & $(-1.63)$ & $(10.90)$ & $(2.96)$ & $(-8.80)$ & $(2.66)$ \\
\hline \multirow[t]{2}{*}{ Strategic governance } & $-0.02 * *$ & 0.00 & $-0.02 * *$ & 0.01 & $0.01 *$ & 0.03 \\
\hline & $(-2.29)$ & $(-1.19)$ & $(-2.12)$ & $(0.19)$ & $(1.76)$ & $(1.38)$ \\
\hline \multirow[t]{2}{*}{ Human capital } & $0.04 * * *$ & $0.01 * * *$ & $0.03 * * *$ & 0.05 & $0.01 * *$ & $0.04 *$ \\
\hline & $(4.49)$ & $(4.32)$ & $(4.20)$ & $(0.85)$ & $(2.45)$ & $(1.96)$ \\
\hline \multirow[t]{2}{*}{ Environment } & $-0.07 * * *$ & $-0.03 * * *$ & $-0.06 * * *$ & $-0.16 * * *$ & $-0.06 * * *$ & $-0.17 * * *$ \\
\hline & $(-7.52)$ & $(-8.88)$ & $(-7.55)$ & $(-2.58)$ & $(-10.81)$ & $(-7.41)$ \\
\hline \multirow[t]{2}{*}{ Stakeholder capital } & -0.01 & 0.00 & 0.00 & $-0.11 *$ & -0.01 & -0.02 \\
\hline & $(-0.71)$ & $(-1.19)$ & $(-0.57)$ & $(-1.89)$ & $(-0.92)$ & $(-1.04)$ \\
\hline \multirow[t]{2}{*}{ RoE } & $0.26^{* * *}$ & $0.11 * * *$ & $0.24 * * *$ & $6.99 * * *$ & $0.36^{* * *}$ & $2.00 * * *$ \\
\hline & $(14.95)$ & $(16.60)$ & $(15.14)$ & $(55.63)$ & $(30.84)$ & $(28.42)$ \\
\hline \multirow[t]{2}{*}{ Size } & $0.14 * * *$ & $0.08 * * *$ & $0.14 * * *$ & 0.06 & $0.16^{* * *}$ & $0.27 * * *$ \\
\hline & $(16.53)$ & $(23.06)$ & $(16.92)$ & $(0.95)$ & $(27.50)$ & $(11.44)$ \\
\hline \multirow[t]{2}{*}{ Basic Materials } & $0.10 *$ & 0.03 & $0.08 *$ & 0.32 & $0.08 * *$ & $0.30 * *$ \\
\hline & $(1.88)$ & $(1.58)$ & $(1.72)$ & $(0.83)$ & $(2.31)$ & $(2.09)$ \\
\hline \multirow[t]{2}{*}{ Industrial } & 0.07 & $0.04 *$ & 0.05 & $0.80 * *$ & $0.23 * * *$ & $0.65 * * *$ \\
\hline & $(1.40)$ & $(1.88)$ & $(1.09)$ & $(2.30)$ & $(7.00)$ & $(5.05)$ \\
\hline \multirow[t]{2}{*}{ Consumer, Non-Cyclical } & $0.28 * * *$ & $0.12 * * *$ & $0.28 * * *$ & $1.71 * * *$ & $0.34 * * *$ & $1.49 * * *$ \\
\hline & $(4.96)$ & $(5.63)$ & $(5.38)$ & $(4.22)$ & $(9.10)$ & $(9.97)$ \\
\hline \multirow[t]{2}{*}{ Healthcare } & $0.71 * * *$ & $0.31 * * *$ & $0.69 * * *$ & $2.42 * * *$ & $0.47 * * *$ & $1.39 * * *$ \\
\hline & (11.98) & $(13.50)$ & $(12.75)$ & $(5.71)$ & (11.99) & $(8.88)$ \\
\hline \multirow[t]{2}{*}{ Consumer, Cyclical } & $0.18 * * *$ & $0.05 * *$ & $0.13 * * *$ & $1.12 * * *$ & $0.16^{* * *}$ & $0.79 * * *$ \\
\hline & $(3.66)$ & $(2.55)$ & $(2.92)$ & $(3.14)$ & $(4.94)$ & $(5.97)$ \\
\hline \multirow[t]{2}{*}{ Telecommunications } & $-0.15^{* *}$ & $-0.07 * *$ & $-0.14 * *$ & 0.78 & $0.08 *$ & $0.53 * * *$ \\
\hline & $(-2.08)$ & $(-2.47)$ & $(-2.18)$ & $(1.56)$ & $(1.71)$ & $(2.84)$ \\
\hline \multirow[t]{2}{*}{ Utilities } & $-0.33 * * *$ & $-0.17 * * *$ & $-0.34 * * *$ & 0.07 & -0.01 & -0.11 \\
\hline & $(-5.33)$ & $(-7.16)$ & $(-6.05)$ & $(0.15)$ & $(-0.24)$ & $(-0.68)$ \\
\hline \multirow[t]{2}{*}{ Financial } & $-0.50 * * *$ & $-0.32 * * *$ & $-0.51 * * *$ & -0.19 & $-0.29 * * *$ & $-0.48 * * *$ \\
\hline & $(-10.41)$ & $(-17.03)$ & $(-11.69)$ & $(-0.54)$ & $(-9.04)$ & $(-3.75)$ \\
\hline \multirow[t]{2}{*}{ Technology } & $0.81 * * *$ & $0.32 * * *$ & $0.76^{* * *} *$ & $2.42 * * *$ & $0.46^{* * *}$ & $1.59 * * *$ \\
\hline & $(13.66)$ & $(14.19)$ & $(14.21)$ & $(5.77)$ & $(11.68)$ & $(10.27)$ \\
\hline \multirow[t]{2}{*}{ Year 2005} & $0.13 * * *$ & $0.09 * * *$ & $0.14 * * *$ & $0.45^{*}$ & $0.26^{* * *}$ & $0.41 * * *$ \\
\hline & $(3.58)$ & $(6.23)$ & $(4.46)$ & $(1.80)$ & $(10.95)$ & $(4.36)$ \\
\hline \multirow[t]{2}{*}{ Year 2006} & $0.20 * * *$ & $0.12 * * *$ & $0.21 * * *$ & $0.54 * *$ & $0.30 * * *$ & $0.56 * * *$ \\
\hline & $(6.53)$ & $(10.25)$ & (7.39) & $(2.49)$ & $(14.83)$ & $(6.96)$ \\
\hline \multirow[t]{2}{*}{ Year 2007} & $0.14 * * *$ & $0.08 * * *$ & $0.15 * * *$ & $0.53 * *$ & $0.20 * * *$ & $0.48 * * *$ \\
\hline & $(4.72)$ & $(6.81)$ & $(5.52)$ & $(2.45)$ & $(9.91)$ & $(6.06)$ \\
\hline \multirow[t]{2}{*}{ Year 2008} & $-0.23 * * *$ & $-0.14 * * *$ & $-0.21 * * *$ & $-0.73 * * *$ & $-0.25 * * *$ & $-0.48 * * *$ \\
\hline & $(-7.80)$ & $(-12.01)$ & $(-7.75)$ & $(-3.46)$ & $(-12.55)$ & $(-6.12)$ \\
\hline \multirow[t]{2}{*}{ Asia } & $-0.58 * * *$ & $-0.25 * * *$ & $-0.50 * * *$ & $-0.68 * *$ & $-0.37 * * *$ & $-1.19 * * *$ \\
\hline & $(-14.19)$ & $(-15.98)$ & $(-13.41)$ & $(-2.35)$ & $(-13.85)$ & $(-11.00)$ \\
\hline Europe & $-0.39 * * *$ & $-0.15 * * *$ & $-0.33 * * *$ & -0.13 & $-0.12 * * *$ & $-0.55 * * *$ \\
\hline & $(-10.27)$ & $(-10.08)$ & $(-9.47)$ & $(-0.50)$ & $(-4.90)$ & $(-5.46)$ \\
\hline North America & $-0.38 * * *$ & $-0.13 * * *$ & $-0.30 * * *$ & -0.19 & $-0.13 * * *$ & $-0.55 * * *$ \\
\hline & $(-9.83)$ & $(-8.73)$ & $(-8.41)$ & $(-0.70)$ & $(-4.93)$ & $(-5.41)$ \\
\hline Sample size & 8938 & 8938 & 8893 & 8972 & 8972 & 8883 \\
\hline R-squared & 0.2207 & 0.3343 & 0.2411 & 0.2821 & 0.3644 & 0.2106 \\
\hline Adjusted $\mathrm{R}^{2}$ & 0.2188 & 0.3326 & 0.2392 & 0.2804 & 0.3628 & 0.2086 \\
\hline
\end{tabular}

Period: 2005-2009. Where: Q, Tobin's q; P/B, Price-to-Book; Strategic governance, Human capital, Environment and Stakeholder capital, the four pillars' subscores; RoE, Return on Equity; Size, logarithm of market capitalization (billion USD); Basic Materials to Technology, dummy variables for the industry sets; Year 2005 to 2008, dummy variables for the corresponding years; Asia, Europe, and North America, dummy variables for the regions. 
Table 9: Robustness checks for regressions with IVA rating

\begin{tabular}{|c|c|c|c|c|}
\hline & $\log (\mathrm{Q})$ & $\log (\mathrm{Q})$ & $\log (\mathrm{P} / \mathrm{B})$ & $\log (\mathrm{P} / \mathrm{B})$ \\
\hline \multirow[t]{2}{*}{ Intercept } & $-0.18 * * *$ & $-0.18 * * *$ & $-0.37 * * *$ & $-0.36 * * *$ \\
\hline & $(-3.31)$ & $(-3.41)$ & $(-4.15)$ & $(-4.06)$ \\
\hline \multirow[t]{2}{*}{ IVA Rating } & $-0.02 * * *$ & $-0.02 * * *$ & $-0.04 * * *$ & $-0.03 * * *$ \\
\hline & $(-4.97)$ & $(-4.70)$ & $(-5.80)$ & $(-5.60)$ \\
\hline \multirow[t]{2}{*}{ RoE } & $0.08 * * *$ & $0.09 * * *$ & $0.27 * * *$ & $0.28 * * *$ \\
\hline & $(9.16)$ & $(9.30)$ & $(17.84)$ & (17.98) \\
\hline \multirow[t]{2}{*}{ Size } & $0.09^{* * *}$ & $0.09 * * *$ & $0.15^{* * *}$ & $0.15 * * *$ \\
\hline & $(17.82)$ & $(17.84)$ & $(17.00)$ & $(16.95)$ \\
\hline \multirow[t]{2}{*}{ Basic Materials } & 0.03 & 0.03 & 0.06 & 0.05 \\
\hline & (1.29) & (1.10) & $(1.40)$ & (1.17) \\
\hline \multirow[t]{2}{*}{ Industrial } & 0.03 & 0.04 & $0.19 * * *$ & $0.19 * * *$ \\
\hline & $(1.31)$ & $(1.42)$ & $(4.48)$ & $(4.46)$ \\
\hline \multirow[t]{2}{*}{ Consumer, Non-Cyclical } & $0.19 * * *$ & $0.19 * * *$ & $0.43 * * *$ & $0.42 * * *$ \\
\hline & $(6.32)$ & $(6.35)$ & $(8.41)$ & $(8.37)$ \\
\hline \multirow[t]{2}{*}{ Healthcare } & $0.25 * * *$ & $0.26 * * *$ & $0.32 * * *$ & $0.33 * * *$ \\
\hline & $(8.40)$ & $(8.66)$ & $(6.46)$ & $(6.56)$ \\
\hline \multirow[t]{2}{*}{ Consumer, Cyclical } & -0.03 & -0.03 & 0.03 & 0.03 \\
\hline & $(-1.05)$ & $(-0.91)$ & $(0.61)$ & $(0.63)$ \\
\hline \multirow[t]{2}{*}{ Telecommunications } & $-0.10 * *$ & $-0.10 * *$ & 0.01 & 0.01 \\
\hline & $(-2.13)$ & $(-2.15)$ & $(0.14)$ & $(0.07)$ \\
\hline \multirow[t]{2}{*}{ Utilities } & $-0.10 * * *$ & $-0.10 * * *$ & $0.11^{*}$ & $0.10^{*}$ \\
\hline & $(-2.72)$ & $(-2.77)$ & (1.74) & (1.67) \\
\hline \multirow[t]{2}{*}{ Financial } & $-0.25 * * *$ & $-0.25 * * *$ & -0.07 & -0.08 \\
\hline & $(-4.96)$ & $(-4.97)$ & $(-0.88)$ & $(-0.93)$ \\
\hline \multirow[t]{2}{*}{ Technology } & $0.18 * * *$ & $0.19^{* * *}$ & $0.23 * * *$ & $0.24 * * *$ \\
\hline & $(6.13)$ & $(6.48)$ & $(4.76)$ & $(4.9)$ \\
\hline \multirow[t]{2}{*}{ Year 2005} & $0.13 * * *$ & $0.13 * * *$ & $0.27 * * *$ & $0.27 * * *$ \\
\hline & $(6.08)$ & (6.19) & $(7.5)$ & $(7.62)$ \\
\hline \multirow[t]{2}{*}{ Year 2006} & $0.14 * * *$ & $0.14^{* * *}$ & $0.26^{* * *}$ & $0.27 * * *$ \\
\hline & $(7.75)$ & $(7.79)$ & $(8.88)$ & $(8.98)$ \\
\hline \multirow[t]{2}{*}{ Year 2007} & $0.11 * * *$ & $0.11 * * *$ & $0.21 * * *$ & $0.21 * * *$ \\
\hline & $(6.15)$ & $(6.15)$ & $(7.2)$ & $(7.25)$ \\
\hline \multirow[t]{2}{*}{ Year 2008} & $-0.17 * * *$ & $-0.17 * * *$ & $-0.27 * * *$ & $-0.27 * * *$ \\
\hline & $(-9.89)$ & $(-9.89)$ & $(-9.59)$ & $(-9.52)$ \\
\hline \multirow[t]{2}{*}{ Asia } & $-0.41 * * *$ & $-0.40 * * *$ & $-0.62 * * *$ & $-0.62 * * *$ \\
\hline & $(-15.17)$ & $(-14.93)$ & $(-13.88)$ & $(-13.86)$ \\
\hline \multirow[t]{2}{*}{ Europe } & $-0.25 * * *$ & $-0.25 * * *$ & $-0.27 * * *$ & $-0.27 * * *$ \\
\hline & $(-9.30)$ & $(-9.12)$ & $(-5.96)$ & $(-6.01)$ \\
\hline \multirow[t]{2}{*}{ North America } & $-0.23 * * *$ & $-0.23 * * *$ & $-0.21 * * *$ & $-0.22 * * *$ \\
\hline & $(-8.44)$ & $(-8.31)$ & $(-4.61)$ & $(-4.71)$ \\
\hline \multirow[t]{2}{*}{$\mathrm{R} \& \mathrm{D}$} & $2.38 * * *$ & $2.20 * * *$ & $2.85 * * *$ & $2.69 * * *$ \\
\hline & $(15.00)$ & $(13.10)$ & $(10.81)$ & $(9.61)$ \\
\hline \multirow[t]{2}{*}{ R\&D * Sales growth } & & $0.17 * * *$ & & 0.08 \\
\hline & & $(3.19)$ & & $(0.91)$ \\
\hline Sample size & 3832 & 3824 & 3833 & 3825 \\
\hline R-squared & 0.3941 & 0.3945 & 0.3886 & 0.3888 \\
\hline Adjusted $\mathrm{R}^{2}$ & 0.3909 & 0.3912 & 0.3854 & 0.3855 \\
\hline
\end{tabular}

Period: 2005-2009. Where: Q, Tobin's $q$; P/B, Price-to-Book; IVA Rating: numerical variable from 1 (CCC) to 7 (AAA); RoE, Return on Equity; Size, logarithm of market capitalization (billion USD); Basic Materials to Technology, dummy variables for the industry sets; Year 2005 to 2008, dummy variables for the corresponding years; Asia, Europe, and North America, dummy variables for the regions, R\&D, research and development expenses divided by the total assets; Sales growth, two-year revenue growth. 
Table 10: Robustness checks for regressions with subscores

\begin{tabular}{|c|c|c|c|c|}
\hline & $\log (Q)$ & $\log (\mathrm{Q})$ & $\log (\mathrm{P} / \mathrm{B})$ & $\log (\mathrm{P} / \mathrm{B})$ \\
\hline \multirow[t]{2}{*}{ Intercept } & $-0.13 * *$ & $-0.14 * * *$ & $-0.29 * * *$ & $-0.28 * * *$ \\
\hline & $(-2.50)$ & $(-2.63)$ & $(-3.18)$ & $(-3.10)$ \\
\hline \multirow[t]{2}{*}{ Strategic governance } & 0.00 & 0.00 & $0.02 * *$ & $0.02 * * *$ \\
\hline & $(0.42)$ & $(0.54)$ & $(2.51)$ & $(2.67)$ \\
\hline \multirow[t]{2}{*}{ Human capital } & $0.01 * *$ & $0.01 * *$ & -0.01 & -0.01 \\
\hline & $(2.14)$ & $(2.30)$ & $(-1.33)$ & $(-1.26)$ \\
\hline \multirow[t]{2}{*}{ Environment } & $-0.06^{* * *}$ & $-0.06 * * *$ & $-0.09 * * *$ & $-0.09 * * *$ \\
\hline & $(-10.73)$ & $(-10.67)$ & $(-9.92)$ & $(-9.93)$ \\
\hline \multirow[t]{2}{*}{ Stakeholder capital } & 0.00 & 0.00 & 0.00 & 0.00 \\
\hline & $(-0.13)$ & $(-0.16)$ & $(0.53)$ & $(0.53)$ \\
\hline \multirow[t]{2}{*}{ RoE } & $0.09 * * *$ & $0.09 * * *$ & $0.28 * * *$ & $0.28^{* * *}$ \\
\hline & $(9.37)$ & $(9.47)$ & $(18.15)$ & $(18.27)$ \\
\hline \multirow[t]{2}{*}{ Size } & $0.10 * * *$ & $0.10 * * *$ & $0.16^{* * *}$ & $0.16^{* * *}$ \\
\hline & $(20.00)$ & $(19.99)$ & $(18.58)$ & $(18.51)$ \\
\hline \multirow[t]{2}{*}{ Basic Materials } & $0.05^{*}$ & 0.04 & $0.08^{*}$ & 0.07 \\
\hline & $(1.83)$ & $(1.63)$ & $(1.86)$ & $(1.62)$ \\
\hline \multirow[t]{2}{*}{ Industrial } & $0.05 *$ & $0.05 * *$ & $0.21 * * *$ & $0.21 * * *$ \\
\hline & $(1.92)$ & $(2.01)$ & $(5.08)$ & $(5.04)$ \\
\hline \multirow[t]{2}{*}{ Consumer, Non-Cyclical } & $0.19 * * *$ & $0.19 * * *$ & $0.43 * * *$ & $0.43 * * *$ \\
\hline & $(6.48)$ & $(6.50)$ & $(8.55)$ & $(8.50)$ \\
\hline \multirow[t]{2}{*}{ Healthcare } & $0.26^{* * *}$ & $0.26 * * *$ & $0.33 * * *$ & $0.33 * * *$ \\
\hline & $(8.69)$ & $(8.89)$ & $(6.68)$ & $(6.72)$ \\
\hline \multirow[t]{2}{*}{ Consumer, Cyclical } & -0.02 & -0.02 & 0.05 & 0.05 \\
\hline & $(-0.76)$ & $(-0.66)$ & $(1.06)$ & $(1.03)$ \\
\hline \multirow[t]{2}{*}{ Telecommunications } & $-0.14 * * *$ & $-0.14 * * *$ & -0.07 & -0.08 \\
\hline & $(-3.16)$ & $(-3.17)$ & $(-0.97)$ & $(-1.03)$ \\
\hline \multirow[t]{2}{*}{ Utilities } & $-0.08 * *$ & $-0.08 * *$ & $0.15 * *$ & $0.15 * *$ \\
\hline & $(-2.14)$ & $(-2.20)$ & $(2.47)$ & $(2.40)$ \\
\hline \multirow[t]{2}{*}{ Financial } & $-0.28 * * *$ & $-0.28 * * *$ & -0.10 & -0.10 \\
\hline & $(-5.53)$ & $(-5.54)$ & $(-1.16)$ & $(-1.21)$ \\
\hline \multirow[t]{2}{*}{ Technology } & $0.19 * * *$ & $0.20 * * *$ & $0.25^{* * *}$ & $0.26^{* * *}$ \\
\hline & $(6.50)$ & $(6.73)$ & $(5.15)$ & $(5.18)$ \\
\hline \multirow[t]{2}{*}{ Year 2005} & $0.12 * * *$ & $0.13 * * *$ & $0.26 * * *$ & $0.26^{* * *}$ \\
\hline & $(5.85)$ & $(5.93)$ & $(7.33)$ & $(7.41)$ \\
\hline \multirow[t]{2}{*}{ Year 2006} & $0.13^{* * *}$ & $0.13 * * *$ & $0.25 * * *$ & $0.25 * * *$ \\
\hline & $(7.32)$ & $(7.34)$ & $(8.59)$ & $(8.67)$ \\
\hline \multirow[t]{2}{*}{ Year 2007} & $0.10^{* * *}$ & $0.10 * * *$ & $0.20 * * *$ & $0.20 * * *$ \\
\hline & $(5.82)$ & $(5.82)$ & $(6.94)$ & $(6.98)$ \\
\hline \multirow[t]{2}{*}{ Year 2008} & $-0.17 * * *$ & $-0.17 * * *$ & $-0.27 * * *$ & $-0.27 * * *$ \\
\hline & $(-9.99)$ & $(-10.00)$ & $(-9.68)$ & $(-9.62)$ \\
\hline Asia & $-0.36 * * *$ & $-0.35 * * *$ & $-0.55 * * *$ & $-0.55 * * *$ \\
\hline & $(-13.33)$ & $(-13.17)$ & $(-12.19)$ & $(-12.24)$ \\
\hline Europe & $-0.22 * * *$ & $-0.22 * * *$ & $-0.23 * * *$ & $-0.23 * * *$ \\
\hline & $(-8.34)$ & $(-8.24)$ & $(-5.08)$ & $(-5.21)$ \\
\hline North America & $-0.23 * * *$ & $-0.23 * * *$ & $-0.2 * * *$ & $-0.21 * * *$ \\
\hline & $(-8.71)$ & $(-8.63)$ & $(-4.58)$ & $(-4.73)$ \\
\hline $\mathrm{R} \& \mathrm{D}$ & $2.54 * * *$ & $2.39 * * *$ & $3.12 * * *$ & $3.01 * * *$ \\
\hline & $(16.2)$ & $(14.39)$ & (11.91) & $(10.82)$ \\
\hline R\&D * Sales growth & & $0.15^{* * *}$ & & 0.04 \\
\hline & & $(2.80)$ & & $(0.50)$ \\
\hline Sample size & 3832 & 3824 & 3833 & 3825 \\
\hline R-squared & 0.4153 & 0.4154 & 0.4042 & 0.4044 \\
\hline Adjusted $\mathrm{R}^{2}$ & 0.4117 & 0.4117 & 0.4006 & 0.4006 \\
\hline
\end{tabular}

Period: 2005-2009. Where: Q, Tobin's q; P/B, Price-to-Book; Strategic governance, Human capital, Environment and Stakeholder capital, the four pillars' subscores; RoE, Return on Equity; Size, logarithm of market capitalization (billion USD); Basic Materials to Technology, dummy variables for the industry sets; Year 2005 to 2008, dummy variables for the corresponding years; Asia, Europe, and North America, dummy variables for the regions, $R \& D$, research and development expenses divided by total assets; Sales growth, two-year revenue growth. 